\title{
Structural Accessibility of Gynecological Nursing Clinics for Users with Motor Disabilities in Basic Health Units
}

\author{
Ana Talyne Pessoa', Beatriz da Silva Lima1, Lorita Marlena Freitag Pagliuca1*, \\ Paula Marciana Pinheiro de Oliveira ${ }^{2}$, Leilane Barbosa de Sousa², \\ Paulo César de Almeida1, Luciana Vieira de Carvalho ${ }^{1}$, Aline Cruz Esmeraldo Áfio ${ }^{1}$ \\ ${ }^{1}$ Departamento de Enfermagem, Universidade Federal do Ceará, Fortaleza, Brasil \\ ${ }^{2}$ Universidade Internacional da Integração da Lusofonia Afro-Brasileira, Fortaleza, Brasil \\ Email: *pagliuca@ufc.br
}

Received 17 September 2015; accepted 26 October 2015; published 29 October 2015

Copyright (C) 2015 by authors and Scientific Research Publishing Inc.

This work is licensed under the Creative Commons Attribution International License (CC BY). http://creativecommons.org/licenses/by/4.0/

(c) (i) Open Access

\begin{abstract}
A quantitative descriptive study aimed to evaluate the physical structure accessibility of gynecological nursing clinics and their bathrooms in basic health units for users with motor disabilities. A checklist tool/instrument was applied for analyzing 16 items in the bathroom and four in the nursing clinic. 157 basic health units were evaluated. In the nursing clinic, counters and tables (79.6\%) were accessible, but stretchers (93\%), seats $(93.6 \%)$ and doors $(87.3 \%)$ were inaccessible; moreover, $\mathbf{1 7 . 8 \%}$ of the units examined proved totally inaccessible. In the bathroom, the items with the best evaluation were the height of the toilet flusher $(47 \%)$ with operation by slight pressure (44.6\%) and the wall-mounted sink (42.7\%). Bathroom doors and turning area/space for wheelchairs were inaccessible. No bathroom reached full accessibility, and $31.2 \%$ were entirely inaccessible. Non-compliance was evident of the standard 9050:2004 of the Brazilian Association of Technical Standards. Raising the awareness of health and engineering professionals is recommended to learn technical accessibility standards and implement them.
\end{abstract}

\section{Keywords}

Nursing, Health Services Accessibility, Disabled Persons

\section{Introduction}

People with disabilities (PD) are those that have long-term impairments, whether being physical, mental, intel"Corresponding author. 
lectual or sensory impairments. Full and effective activities of these people in society on a full and equal basis with others may be blocked because of the characteristics and environmental difficulties they may encounter that can prevent their social interaction [1].

In 2010, Brazil had 45,606,048 (23.9\%) people who claimed having at least one disability, with the highest prevalence rate being in the Northeast with $26.63 \%$, presenting an elevated position compared to the national average. As to gender, analyses had shown that $26.5 \%$ of the female population ( 25.8 million) had some disability compared with $21.2 \%$ of the male population ( 19.8 million). In this analysis, the female population had higher percentages of disability for all races or colors declared [2].

Physically disabled women report that they face distressing situations during consultations in health services. However, health professionals, especially nurses and the team leaders, responsible for gynecological care in the basic health units, must establish bonds of trust with users to promote quality care favoring sexual health promotion [3].

Primary health care is characterized as a set of actions that include health promotion and protection, disease prevention, diagnosis, treatment, rehabilitation, harm reduction and maintenance of health, individually and collectively. It should be a gateway for users. It follows the principles of universality, accessibility, connectivity, continuity of care, comprehensiveness of care, accountability, humanization, equity and social participation. Subjects are considered as an individual part of a socio-cultural environment, with the objective to develop comprehensive care [4].

Nurses are important members of the multidisciplinary team that is part of the Family Health Strategy (FHS) [5]. Among the actions carried out by primary care teams, those related to the control of cervical cancer (CC) can be highlighted. The following national goals have been established for CC control: expanding Pap test coverage in women between 25 and 64 years of age; treating $100 \%$ of women diagnosed with precursor cancer lesions; improving CC and breast cancer screening; universalizing these tests for all women, regardless of income, race, or color, thus reducing inequalities [6].

Among the main factors affecting the performing of Pap Smear examinations for wheelchair users, the design inadequacy of health services to this group of women can be emphasized, apart from the health team's unpreparedness in handling handling/treating these women with this particular condition [7]. The Ministry of Health's goals can only be achieved when all sexually active women have access to gynecological care. It appears that adult women with motor disabilities are culturally perceived as asexual and are excluded from the target audience for active $\mathrm{CC}$ control. Added to this scenario are physical barriers, which prevent these women from feeling empowered to seek gynecological care.

Women with disabilities are left on the fringes of the women's movement and the civil rights movement of this social group. It can be said that disability issues tend to be a considerable problem regarding public health and women's health. This share of the population has inexpressive actions addressed to their needs in primary health care services. Female clients in general have this care about their sexual and reproductive rights guarantee; on the other hand the disabled women are more vulnerable [8].

In Brazil, sexual and reproductive health interventions of women with disabilities were discussed and documented by the Ministry of Health for their promotion in the health network. However, public policies and care practices are still very incipient. Thus, women with disabilities do not receive adequate reproductive and sexual assistance. When they do exist, such assistance faces several barriers, especially when referring to physical disabilities [9].

In the face of the problems experienced by this population with regard to attending gynecological nursing consultations, this study aiming at evaluating the structural accessibility of gynecological nursing clinics for users with motor disabilities in basic health units (BHUs) has become relevant.

\section{Method}

A descriptive study using a quantitative approach composed of ordered and disciplined procedures used to acquire numeric information that resulted from formal measurement and analyzed in statistical procedures [10].

The study was carried out in BHUs of Maciço de Baturité's municipalities due to its geographic peculiarities and the lack of previous studies. Ceara state consists of 184 municipalities with 22 micro-regions and five macro-regions which make up the State Health System [11]. It was performed from August 2014 to January 2015. Access to the lists of health units was carried out through the National Registry of Health Facilities of the Min- 
istry of Health. Exclusion criteria considered units that were leased in temporary spaces, were under construction or had access prevented due to hazard.

Data collection was conducted by applying a check-list instrument entitled Physical Accessibility Registry for Basic Health Units, which evaluated 16 items in the bathrooms and 4 items in the nursing clinics based on the Brazilian Standard (NBR) 9050:2004 of the Brazilian Association of Technical Standards (ABNT). This Standard sets criteria and technical parameters to be observed for when design, construction, installation and alteration of buildings, houses, urban spaces and equipment are done in order to obtain adequate conditions of accessibility [12].

The instrument offered information on unit identification, location (rural or urban) and municipality to which it belonged. For this study, the entry corresponding to Nursing Clinics was analyzed as described below.

Environmental evaluation was performed by analyzing the internal area of the clinics and their bathrooms. The evaluation of internal areas consisted of the nurse's clinic entrance door width that should be at least $80 \mathrm{~cm}$ wide; counters and work stations, which should be 75 to $85 \mathrm{~cm}$ from the floor (height); seats for the users/public, which should have a minimum of $45 \mathrm{~cm}$ depth, $46 \mathrm{~cm}$ from the floor (height), with grab bars or arm support; and a stretcher for clinical examination, which should be 49 to $53 \mathrm{~cm}$ from the floor (height) to facilitate user transfer.

In the private bathrooms the door was evaluated, which should also have a minimum width of $80 \mathrm{~cm}$; maneuvering clearance area for a wheelchair, ensuring diagonal, lateral and perpendicular movement and $360^{\circ}$ rotation, with the following dimensions being a reference: $1.20 \mathrm{~m}$ for straight movement; $1.20 \mathrm{~m}$ by $1.20 \mathrm{~m}$ for $90^{\circ}$ rotation; $1.20 \mathrm{~m}$ by $1.50 \mathrm{~m}$ for $180^{\circ}$ rotation and $1.50 \mathrm{~m}$ by $1.50 \mathrm{~m}$ for $360^{\circ}$ rotation; clear sanitary and accessories that do not require transposition should be $1.20 \mathrm{~m}$ by $80 \mathrm{~cm}$; presence of horizontal grab bars on the side and back walls with sanitary basin should be present, being at least $80 \mathrm{~cm}$ in length and $75 \mathrm{~cm}$ from the floor; the seat of the sanitary bowl should be $46 \mathrm{~cm}$ from the floor, presence of sanitary napkin disposal units 1.50 to $60 \mathrm{~cm}$ from the floor and $15 \mathrm{~cm}$ from the front edge of the sanitary bowl; flush control maximum height of $1 \mathrm{~m}$ from the floor and working with light pressure; and a wall-mounted sink being a minimum height of 78 to $80 \mathrm{~cm}$ from the floor with a single lever faucet.

The instrument was filled out by the following possibilities: Accessible, if environment or object was suitable to the characteristics provided by item; Inaccessible when the features proposed in the item were not met; Non-existent if environment does not have object/device to be evaluated; Not Applicable when item addressed was not necessary in the assessed site; Not Collected, if the UBS or sector was not in use or closed at the time of data collection; Renovation, if the space provided the item is under renovation; Absent, if the UBS does not have the environment to be analyzed.

Data was processed by SPSS version 20.0 and later organized into tables. Mean and standard deviation were calculated. This study was approved by the Research Ethics Committee of the University of International Integration of African-Brazilian Lusophone No. 652.134/2014 and complies with the principles of Resolution 466/ 2012 of the National Health Council.

\section{Results}

The sample consisted of 157 public health units and the results were organized into four tables. Table 1 and Table 2 feature data analyzed from gynecological clinics, highlighting the analyzed variables and the frequency of accessible items, respectively. Table 2 and Table 3 present data from bathrooms and the frequency of accessible items.

Table 1 shows accessibility data referring to doors, counters and work stations, and seats and stretchers.

Regarding width of nursing clinic's entrance doors, most units were inaccessible (87.3\%); counters and work stations were mostly accessible (79.6\%); seats and stretchers were found to be considerably inaccessible $(93.6 \%)$.

Table 2 shows distribution of the number of accessible items evaluated in nursing clinics' internal area.

In the internal area of nursing clinics, the following were evaluated: doors, counters/work stations, seats and stretchers. If these items are accessible in all units, there would be a total of 628 affirmative responses. However, no available items were observed in $28(17.8 \%)$ units, $108(68.8 \%)$ had one item and $21(13.4 \%)$ had two items. In other words, no unit showed accessibility for three or four items analyzed.

Table 3 highlights accessibility conditions analyzed in the bathroom of nursing clinics, comprised of a door, maneuvering clearance area, grab bars, sanitary bowl, trash bin, flush control, sink and faucet. 
Table 1. Distribution of the number of HBUs analyzed regarding accessibility of the gynecological nursing clinics.

\begin{tabular}{cccccc}
\hline \multirow{2}{*}{ Variables } & Accessible & Inaccessible & Non-existent & Renovations & Not collected \\
\cline { 2 - 6 } & $\mathbf{n}(\mathbf{\%})$ & $\mathbf{n}(\mathbf{\%})$ & $\mathbf{n}(\mathbf{\%})$ & $\mathbf{n}(\mathbf{\%})$ & n (\%) \\
\hline Doors & $19(12.1)$ & $137(87.3)$ & - & $1(0.6)$ & - \\
Counters and work stations & $125(79.6)$ & $29(18.5)$ & $1(0.6)$ & $1(0.6)$ & $1(0.6)$ \\
Seats & $5(3.2)$ & $147(93.6)$ & $3(1.9)$ & $1(0.6)$ & $1(0.6)$ \\
Stretchers & $1(0.6)$ & $147(93.6)$ & $7(4.5)$ & $1(0.6)$ & $1(0.6)$ \\
\hline
\end{tabular}

Table 2. Frequency of accessible items in internal areas of gynecological nursing clinics according to evaluated BHUs.

\begin{tabular}{cccc}
\hline Accessible & N & $\%$ \\
\hline 0 & 28 & 17.8 \\
1 & 108 & 68.8 \\
2 & 21 & 13.4 \\
\hline
\end{tabular}

Table 3. Distribution of the number of BHUs s analyzed regarding bathroom accessibility in gynecological nursing clinics.

\begin{tabular}{|c|c|c|c|c|c|c|}
\hline \multirow{2}{*}{ Variables } & Accessible & Inaccessible & Inexistent & Renovation & Not collected & Absent \\
\hline & n (\%) & n (\%) & n (\%) & n (\%) & n (\%) & n (\%) \\
\hline \multicolumn{7}{|l|}{ Bathrooms } \\
\hline Door & $7(4.5)$ & $102(65.0)$ & - & $1(0.6)$ & $9(5.7)$ & $38(24.2)$ \\
\hline \multicolumn{7}{|l|}{ Maneuvering clearance area } \\
\hline 1.20 straight movement & $30(19.1)$ & $84(53.5)$ & - & $1(0.6)$ & $4(2.5)$ & $38(24.2)$ \\
\hline $1.20 \times 1.2090^{\circ}$ rotation & $16(10.2)$ & $98(62.4)$ & - & $1(0.6)$ & $4(2.5)$ & $38(24.2)$ \\
\hline $1.20 \times 1.50180^{\circ}$ rotation & $12(7.6)$ & $102(65.0)$ & - & $1(0.6)$ & $4(2.5)$ & $38(24.2)$ \\
\hline $1.50 \times 1.50360^{\circ}$ rotation & $7(4.5)$ & $107(68.2)$ & - & $1(0.6)$ & $4(2.5)$ & $38(24.2)$ \\
\hline \multicolumn{7}{|l|}{ Transferring } \\
\hline $1.20 \times 0.80$ free space & $6(3.8)$ & $108(68.8)$ & - & $1(0.6)$ & $4(2.5)$ & $38(24.2)$ \\
\hline Side and back grab bars & - & $14(8.9)$ & $100(63.7)$ & $1(0.6)$ & $4(2.5)$ & $38(24.2)$ \\
\hline Horizontal grab bars & - & $5(3.2)$ & $109(69.4)$ & $1(0.6)$ & $4(2.5)$ & $38(24.2)$ \\
\hline Lateral grab bars & - & $6(3.8)$ & $108(68.8)$ & $1(0.6)$ & $4(2.5)$ & $38(24.2)$ \\
\hline Sanitary bowl & $1(0.6)$ & $113(72.0)$ & - & $1(0.6)$ & $4(2.5)$ & $38(24.2)$ \\
\hline Napkin disposal units & $1(0.6)$ & $73(46.5)$ & $40(25.5)$ & $1(0.6)$ & $4(2.5)$ & $38(24.2)$ \\
\hline \multicolumn{7}{|l|}{ Flush } \\
\hline Maximum height & $74(47.1)$ & $37(23.6)$ & $3(1.9)$ & $1(0.6)$ & $4(2.5)$ & $38(24.2)$ \\
\hline Light pressure & $70(44.6)$ & $40(25.5)$ & $4(2.5)$ & $1(0.6)$ & $4(2.5)$ & $38(24.2)$ \\
\hline \multicolumn{7}{|l|}{ Wall-mounted } \\
\hline Sink & $67(42.7)$ & $42(26.8)$ & $5(3.2)$ & $1(0.6)$ & $4(2.5)$ & $38(24.2)$ \\
\hline 78 to $80 \mathrm{~cm}$ from the floor & $26(16.6)$ & $83(52.9)$ & $5(3.2)$ & $1(0.6)$ & $4(2.5)$ & $38(24.2)$ \\
\hline Single lever faucet & $3(1.9)$ & $106(67.5)$ & $5(3.2)$ & $1(0.6)$ & $4(2.5)$ & $38(24.2)$ \\
\hline
\end{tabular}

It is worth noting that of the 157 units evaluated, there were no bathrooms in 38 for the exclusive use by women; when present, they mostly had inaccessible doors and no maneuvering clearance area; lack of grab bars; mostly inaccessible paper towel disposal units and trash bins; flush control at appropriate height, but working with light pressure; wall-mounted sink but at inaccessible height and absence of single lever faucet.

Table 4 shows the distribution of the total number of accessible items in all bathrooms of nursing clinics evaluated. 
Table 4. Frequency of accessible bathroom items in nursing clinics according to evaluated BHUs.

\begin{tabular}{cccc}
\hline Accessible & $\mathbf{N}$ & \% \\
\hline 0 & 49 & 31.2 \\
1 & 14 & 8.9 \\
2 & 31 & 19.7 & 21.0 \\
4 & 33 & 11.5 \\
5 & 4 & 2.5 \\
6 & 4 & 2.5 \\
7 & 3 & 1.9 \\
\hline
\end{tabular}

Most bathrooms had no accessible items (49\% - 31.2\%). Eight was the maximum accessible items found for the 16 items evaluated in bathrooms, and was in only one (0.6\%) unit. If BHUs were all accessible, the total accessible items would be 2512 .

\section{Discussion}

Ceará state corresponds to the third most populous state in the Northeast region, totaling at least 2.3 million people with disabilities. The percentage of the population with a disability living in the state $(27.69 \%)$ exceeds the northeastern $(26.63 \%)$ and the national $(23.92 \%)$ rates. The most common disability is visual $(22.15 \%)$, followed by motor-disability (8.08\%) and hearing (6.23\%) [2] [4].

The population of Maciço de Baturité consists of 625,524 inhabitants spread over 16 municipalities that are organized into two regions: Regional Coordination of Health 3 based in Maracanaú, including the municipalities of Maracanaú, Acarape, Barreira, Guaiuba, Maranguape, Pacatuba , Palmácia and Redenção; and Regional Coordination of Health 4 based in Baturité, and its other municipalities: Aracoiaba, Aratuba, Capistrano, Guaramiranga, Itapiúna, Mulungu and Pacoti [11].

Women with disabilities are prevalent in all municipalities in the Maciço de Baturité region, totaling 125,428 women, of which 92,926 live in the urban area and 32,502 live in rural areas [2]

The presented data indicate the importance of the creation and implementation of public policies being crucial to recognize and represent all the people with their diversity to effectively operate in the social control and guarantee rights of this significant portion of the population [13].

Most people face problems in access to health services, however disability people face the same obstacles and specific additional others [14]. The inclusion of people with disabilities in health services is achieved through architectural planning, which guarantees the right of access and mobility quickly and safely. A study [15] showed that inadequacies in the physical structure of health facilities hinder mobility on site, reducing the opportunity of equal service use. Investigating the difficulties encountered by disability people in accessing health services provides subsidies for properly planning health, thereby structuring and improving services that attend this population group.

The front door to the nurses' clinic serves as a basic means of access to the interior of this environment and ensures the user their right to come and go. However, as noted, the overwhelming majority was inaccessible. Therefore, the user who moves around with the aid of a wheelchair is prevented from entering the nursing office and will need help to enter the room, compromising their autonomy and independence.

Welcoming of gynecological consultations starts at the moment of service demand, but its significant value is in the moment patients enter the nursing clinic. Therefore, obstacles to privacy interfere with the quality of care [16].

Working stations were accessible, facilitating the communication between professionals and users, since it favors proper encounters and increased bonding. Unlike those, the seats were inaccessible (93.6\%), thus hindering user mobility.

Health professionals are responsible for promoting an environment of trust and respect for patients to feel 
comfortable during consultation and thus experience this moment without fear to express difficulties and/or concerns [3]. The stretcher used for transferring patients with motor disabilities from their wheelchair to gynecological examinations was inaccessible in $93.6 \%$ of evaluated practices, augmenting this public's evasion to this kind of service, as the stretcher is an indispensable item for the user's comfort but was inaccessible.

The analysis of the gynecological nursing clinics' internal area showed that for the 628 items evaluated in the internal areas of 157 nursing clinics, a maximum of two positive responses was found in only $21(13.4 \%)$ of them; and most units (68.8\%) only had one accessible item. Women with motor disabilities avoiding consultations related to sexual and reproductive health is explained based on this finding. Inadequate physical infrastructure and furniture significantly contribute to public evasion of services provided by nursing in primary care, and especially in gynecological consultations, which require a comfortable and private environment for patients and professionals.

Preceding the performance of gynecological consultations and the collection of cervical examination materials, women must have an accessible bathroom adjacent to the gynecological nursing examination rooms available to them; in this way, users gain autonomy to prepare for the exam, and have their individuality and privacy respected. Again, 38 clinics had no bathrooms, and where available they $(65.0 \%)$ were inaccessible, which prevents users with motor disabilities, particularly those who use wheelchairs, from entering this space.

The approaching area to the sanitary bowl must allow user transfer before and after use. But mostly, the space intended for transferring was inadequate. Grab bars help women with motor limitation to make the transfer from the wheelchair to the sanitary bowl; they should be placed in convenient locations and at heights which allow their use. Of the 157 units evaluated, $63.7 \%$ did not have this item, and no units had accessible grab bars, meaning that when present they were placed at inappropriate places and lost their functionality. Most toilets (72.0\%) did not meet proper height, along with most paper towel disposal units (46.5\%), and $25.5 \%$ did not even have any paper towels. Proper sanitary height requires less effort for transferring, as well as a flush control lower than a meter from the floor and working by light pressure; sanitary height was accessible in $47.1 \%$ of the units and $44.6 \%$ worked by light pressure flush.

Column sinks prevent wheelchair approximation, and also when height is over $80 \mathrm{~cm}$ above the floor they require additional effort for approaching and using the faucet; which should be of single lever type where a simple up and down lever movement with light pressure allows for proper hand hygiene/washing; the analysis showed that most sinks did not have columns, facilitating the approximation of wheelchair user to perform hand hygiene. However, most of these sinks (52.9\%) had inadequate height, thereby hindering faucet reach by the user; faucets with rounded heads are difficult to use with wet hands, particularly for people with diminished strength. Faucets with movement sensors, which are hygienic because they do not require touch and are economical in rationing the use of water were not identified in any of the evaluated units.

These results corroborate another study [15] which revealed structural inadequacy of disability people toilets in health facilities, hampering access to these environments. This is partly due to a lack of knowledge of the legal system that protects disability people and partly because of the naturalization of actions of social actors; architectural and attitudinal barriers are imposed and represent symbolic violence against these people. It is unanimous that disability people face greater difficulties in access among users of the Unified Health System [17]. There are records showing that most health professionals do not receive specific training to attend to disability people during graduation, generating professionals who are unaware of the specific needs of this population segment [18].

Bathroom analysis revealed that the inaccessibility was predominant in the categories of door width and wheelchair maneuvering clearance area. Under these conditions, overweight or pregnant women also have compromised access and literally have to enter bathrooms backwards if they need to use the toilet. Tiny, low and uncomfortable toilets put at risk the safety of people with motor limitations and those who are overweight. Thus, the use of the sanitary bowl, flush control and paper towel disposals are impossible. Personal hygiene at the time of gynecological consultations is of utmost importance for enabling security and comfort to the patient.

To enable an overview of the accessibility assessment of gynecological nursing clinics' internal areas and their respective bathrooms, the area inside had four items evaluated in a sample composed of 157 clinics, so there should be 628 accessible items. As for bathrooms, 16 items of accessibility were evaluated totaling 1904 items that should be accessible, noting that 38 of the clinics did not have bathrooms. There were only two maximum accessible items of internal areas, with these being in only 21 of the analyzed clinics, and the most accessible item were the working stations (125). Doors were inaccessible in 137 clinics, so a wheelchair user could 
not go through the door, and at 125 units they could approach their wheelchair to the interview table, but in only one could they transfer to the examination table. A woman with a motor disability without a wheelchair does not even have a chair at her disposal in the clinic where she could sit comfortably and safely, considering they were only accessible in five BHUs.

So, a moment that is supposed to be enlightening and welcoming turns out to be an invasion of privacy and a major constraint which these users need to go through because of the inadequacy of physical infrastructure and lack of basic and necessary inputs to facilitate the service provided.

Low investment in professional training and health units being unable to absorb the demand and difficulties of municipal and state managers to define and establish flow in the various levels of care are aspects that can contribute to late diagnosis of CC and hinder its treatment [19]. A lack of available physical structure hinders and sometimes makes it impossible for users with physical disabilities to feel welcomed to participate in social life. They do not feel inclined to attend health services, since they are unable to offer minimum comfort and independence for moving around inside. Thus, a lack of adequate physical structure ends up excluding this population from gynecological nursing consultations.

Public policies and programs for women with disabilities exist, however their implementation is still inadequate and exclusionary. There is a considerable lack of knowledge on technical accessibility standards. The promotion of new ways of thinking, acting, building, communicating and using public resources is urgent in order to guarantee women with physical disabilities' their proper rights in health services. We express the need to disseminate such knowledge, essential for operationalizing health attention.

Society needs to be structured with inclusion and participation of all, by conducting quantitative research of this portion of the population to develop specific actions and professional training to attend them, considering that more than just technical standards is necessary; also awareness and sensitivity to the reality of this group in order to serve them in their basic and specific human needs.

\section{Conclusions}

The study results showed that BHUs had inaccessible physical structures, making the access of women with physical disabilities for gynecological consultations difficult and even impossible. Entrance doors, seats and stretchers in general were inaccessible in all clinics. Stretchers available to perform gynecological examinations were present in only one unit. In general, only working stations and counters were accessible.

With regard to the restrooms, we can mention the inadequate size, preventing freedom of movement and transferring to the sanitary bowl, so that users can get around with the aid of a wheelchair. Doors with tiny openings, and sanitary equipment such as a sanitary toilet and paper towel disposal units were mostly inaccessible; flushing and its operation by slight pressure were mostly accessible; grab bars were absent or often attached to inappropriate places, compromising their functionality; most of the sinks had no columns, facilitating approximation for their correct use, but most had inadequate height and the lack of single lever faucets was observed in most units. As a result, improperly distributed objects make it an uncomfortable and impossible environment to be used by a person in a wheelchair during preparation for gynecological consultations.

The exclusion of the female population with motor disabilities to such care exists because of prejudices linked to the myth that disabled people do not engage in sexual intercourse, and is exacerbated when the physical structure of gynecological clinics presents inaccessibility to women with physical disabilities.

It is urgent to clarify to administrators/managers and professionals who attend people with disabilities in health facilities about their proper care, thus guaranteeing them their right to access health care. This study can contribute to changes from its assessment of the reality and by arranging appropriate standards for structuring institutions. It also reinforces the need for deepening the theme because of the little amount of explored literature on the subject.

It is urgent to clarify managers and health professionals about the characteristics and needs of people with disabilities to access health facilities and their proper care, thus guaranteeing them their right to access health care. This study contributes to changes from assessing the reality and arrangement of appropriate standards for structuring institutions. It also reinforces the need for expanding the theme due to the low quantity of literature on the subject.

The study results will be presented and discussed with managers of health departments, health professionals and related fields that collaborate in the planning and implementation of the physical areas and equipment in 
health facilities. It is believed that this action will be a step to awaken an attentive eye to the physical accessibility issues of disabled people.

Among the limitations found in the study, we can mention the scarce amount of literature to discuss the data; the sample loss, although less than $10 \%$, in this units was far from the municipal capital and restricted opening hours being incompatible with the data collection; and finally, professional resistance to allow the data collection.

\section{Acknowledgements}

To Fundação Cearense de Apoio ao Desenvolvimento Científico e Tecnológico and Conselho Nacional de Desenvolvimento Científico e Tecnológico, for the financial support and encouraging the development of this research.

\section{References}

[1] Secretaria de Direitos Humanos (2012) Convenção sobre os Direitos das Pessoas com Deficiência: Protocolo Facultativo à Convenção sobre os Direitos das Pessoas com Deficiência: Decreto Legislativo $n^{\circ}$ 186, de 09 de julho de 2008: Decreto $\mathrm{n}^{\circ}$ 6.949, de 25 de agosto de 2009. Secretaria de Direitos, Brasília. http://www.pessoacomdeficiencia.gov.br/app/sites/default/files/publicacoes/convencaopessoascomdeficiencia.pdf

[2] Instituto Brasileiro de Geografia e Estatística (2010) Censo demográfico: Pessoas com Deficiência. Instituto Brasileiro de Geografia e Estatística, Rio de Janeiro.

http://www.ibge.gov.br/home/estatistica/populacao/censo2010/caracteristicas_religiao_deficiencia/caracteristicas_relig iao deficiencia tab pdf.shtm

[3] Baptista, R.S., Pagliuca, L.M.F., Sampaio, A.F.A. and França, I.S.X. (2014) Sexuality: Experience of Women with Physical Disabilities. Open Journal of Nursing, 4, 920-927.

http://file.scirp.org/Html/3-1440383 52125.htm

http://dx.doi.org/10.4236/ojn.2014.413098

[4] Brasil. Ministério da Saúde (2012) Política Nacional de Atenção Básica. Brasília: Ministério da Saúde. http://189.28.128.100/dab/docs/publicacoes/geral/pnab.pdf

[5] Melo, M.C.S.C., Vilela, F., Salimena, A.M.O. and Souza, I.E.O. (2012) O Enfermeiro na Prevenção do Câncer do Colo do Útero: O Cotidiano da Atenção Primária. Revista Brasileira de Cancerologia, 58, 389-398.

http://www1.inca.gov.br/rbc/n_58/v03/pdf/08_artigo_enfermeiro_prevencao_cancer_colo_utero_cotidiano_atencao_pr imaria.pdf

[6] Brasil. Secretaria de Atenção à Saúde. Departamento de Atenção Básica (2013) Controle dos cânceres do colo do útero e da mama. Ministério da Saúde, Brasília. http://bvsms.saude.gov.br/bvs/publicacoes/controle canceres colo utero 2013.pdf

[7] Silva, M.G.O., Lopes, M.I. and Costa, P.V.L. (2014) Fatores que interferem na realização do exame papanicolau em mulheres cadeirantes. Revista Interdisciplinar, 7, 99-105.

http://revistainterdisciplinar.uninovafapi.edu.br/index.php/revinter/article/view/436/pdf_163

[8] Nicolau, S.M., Schraiber, L.B. and Ayres, J.R.C.M. (2013) Mulheres com deficiência e sua dupla vulnerabilidade: Contribuições para a construção da integralidade em saúde. Ciência \& Saúde Coletiva, 18, 863-872.

http://www.scielo.br/scielo.php?script=sci arttext\&pid=S1413-81232013000300032 http://dx.doi.org/10.1590/s1413-81232013000300032

[9] Carvalho, C.F.S., Brito, R.S. and Medeiros, S.M. (2014) Contextual Analysis of Gynaecological Care Provided to Women with Physical Disability. Revista Gaúcha Enfermagem, 35, 114-117. http://www.scielo.br/scielo.php?pid=S1983-14472014000400114\&script=sci_arttext http://dx.doi.org/10.1590/1983-1447.2014.04.45335

[10] Polit, D.F., Beck, C.T. and Hungler, B.P. (2011) Fundamentos de pesquisa em enfermagem. 6th Edition, Artmed, Porto Alegre.

[11] Coordenadoria Regional de Saúde (2010) $3^{\mathrm{a}}$ e $4^{\circ}$ CRES compõe a Macrorregião de Fortaleza. http://www.saude.ce.gov.br/index.php/regionalizacao

[12] Associação Brasileira de Normas Técnicas (2004) NBR 9050: Acessibilidade a edificações, mobiliário, espaços e equipamentos urbanos. Associação Brasileira de Normas Técnicas, Rio de Janeiro.

[13] Conselho Nacional dos Direitos da Pessoa com Deficiência (2012) Cartilha Orientadora para Criação e Funcionamento dos Conselhos de Direito da Pessoa com Deficiência. Conselho Nacional dos Direitos da Pessoa com Deficiência. 
Secretaria dos Direitos Humanos, Brasília; CONADE, Brasília.

http://www.pessoacomdeficiencia.gov.br/app/sites/default/files/arquivos/\%5Bfield_generico_imagens-filefield-descript ion $\% 5 \mathrm{D} 145 . \mathrm{pdf}$

[14] Eide, A.H., Mannan, H., Khogali, M., Van Rooy, G., Swartz, L., Munthali, A., Hem, K., MacLachlan, M. and Dyrstad, K. (2015) Perceived Barriers for Accessing Health Services among Individuals with Disability in Four African Countries. PLOS ONE, 10. http://journals.plos.org/plosone/article?id=10.1371/journal.pone.0125915 http://dx.doi.org/10.1371/journal.pone.0125915

[15] Castro, S.S., Lefèvre, F., Lefèvre, A.M.C. and Cesar, C.L.G. (2011) Accessibility to Health Services by Persons with Disabilities. Revista de Saúde Pública, 45, 99-105.

http://www.scielosp.org/scielo.php?script=sci arttext\&pid=S0034-89102011000100011\&lng=en\&nrm=iso http://dx.doi.org/10.1590/S0034-89102010005000048

[16] Mendonça, F.A.C., Sampaio, L.R.L., Linard A.G., Silva R.M. and Sampaio L.L. (2011) Acolhimento e vínculo na consulta ginecológica: Concepção de enfermeiras. Revista Rene, 12, 57-64.

http://www.revistarene.ufc.br/revista/index.php/revista/article/view/109

[17] França, I.S.X., Pagliuca, L.M.F., Baptista, R.S., França, E.G.F., Coura, A.S. and Souza, J.A. (2010) Violência simbólica no acesso das pessoas com deficiência às unidades básicas de saúde. Revista Brasileira de Enfermagem, 63, 964-970. http://www.scielo.br/scielo.php?pid=S0034-71672010000600015\&script=sci_arttext http://dx.doi.org/10.1590/S0034-71672010000600015

[18] Rebouças, C.B.A., Cezario, K.G., Oliveira, P.M.O. and Pagliuca, L.M.F. (2011) People with Physical and Sensory Deficits: Perceptions of Undergraduate Nursing Students. Acta Paulista de Enfermagem, 24, 80-86. http://www.scielo.br/pdf/ape/v24n1/en v24n1a12.pdf http://dx.doi.org/10.1590/S0103-21002011000100012

[19] Brito-Silva, K., bezerra, A.F.B., Chaves, L.D.P. and Tanaka, O.Y. (2014) Integrality in Cervical Cancer Care: Evaluation of Access. Revista de Saúde Pública, 48, 240-248.

http://www.scielosp.org/pdf/rsp/v48n2/en 0034-8910-rsp-48-2-0240.pdf http://dx.doi.org/10.1590/S0034-8910.2014048004852 